THE HARVARD UNIVERSITY PRESS FAMILY HEALTH GUIDES 
This book is meant to educate, but it should not be used as a substitute for personal medical advice. Readers should consult their physicians for specific information concerning their individual medical conditions. The author has done his best to ensure that the information presented here is accurate up to the time of publication. However, as research and development are ongoing, it is possible that new findings may supersede some of the data presented here.

This book contains references to actual cases the author has encountered. However, names and other identifying characteristics have been changed to protect the privacy of those involved.

Many of the designations used by manufacturers and sellers to distinguish their products are claimed as trademarks. Where those designations appear in this book and Harvard University Press was aware of a trademark claim, then the designations have been printed in initial capital letters (for example, Coumadin). 


\title{
Stroke and the Family
}

\section{A NEW GUIDE}

\author{
Joel Stein, M.D.
}

HARVARD UNIVERSITY PRESS

Cambridge, Massachusetts

London, England

2004 
Copyright (C) 2004 by the President and Fellows of Harvard College All rights reserved

Printed in the United States of America

\section{Library of Congress Cataloging-in-Publication Data}

Stein, Joel.

Stroke and the family : a new guide / Joel Stein.

p. cm.-(The Harvard University Press family health guides)

Includes bibliographical references and index.

ISBN 0-674-01513-4 (cloth : alk. paper)—ISBN 0-674-01667-X (pbk. : alk. paper)

1. Cerebrovascular disease-Patients-Family relationships. I. Title. II. Series.

RC388.5.S785 2004

$362.196^{\prime} 81-\mathrm{dc} 22$

2004052291

Drawings by Arleen Frasca 
To my wife,

Joanne, for her unconditional love and support

To my children,

Daniel, Joshua, and Aliza, who bring joy to my life 
